International Research Journal of Management, IT \& Social Sciences
Available online at https://sloap.org/journals/index.php/irjmis/
Vol. 6 No. 5, September 2019, pages: 101 107
ISSN: 2395-7492
https://doi.org/10.21744/irjmis.v6n5.704

\title{
The Pecking Order Theory Testing on Company Life Cycle
}

Ida Ayu Kayika Apsari ${ }^{\text {a }}$ Ni Ketut Rasmini ${ }^{b}$

Article history:

Received: 27 March 2019

Accepted: 31 May 2019

Published: 23 August 2019

\section{Keywords:}

company;

growth;

life cycle;

mature;

pecking order theory;

\begin{abstract}
This study was conducted on 49 property and real estate companies listed on the Indonesia Stock Exchange. Year of observation in this research is the year 2013-2017. Research samples of 49 property and real estate companies are grouped based on their life cycle criteria based on the company's net sales for 5 years. After the company is grouped based on its life cycle, multiple linear regression tests are used to test whether the company's Life Cycle affects the company in applying Pecking Order Theory in its funding decision. After multiple linear regression tests, the company in the Growth and Mature cycle stages is compared to whether firm growth is stronger than mature in applying Pecking Order Theory. The results of this study obtained Life Cycle property and real estate companies listed on the Stock Exchange did not significantly affect the Pecking Order Theory. The life cycle of the company does not affect the company in determining its funding decision. The life cycle of the company does not affect the company to apply the Pecking Order Theory in determining its capital structure. Companies that have been grouped according to their life cycle, in determining their capital structure, whether the company will fund with internal funds or external funds company, not based on the life cycle of the company.
\end{abstract}

2395-7492@ Copyright 2019. The Author. This is an open-access article under the CC BY-SA license (https://creativecommons.org/licenses/by-sa/4.0/) All rights reserved.

\author{
Author correspondence: \\ Ida Ayu Kayika Apsari, \\ Faculty of Economic and Business Udayana University, Denpasar, Indonesia. \\ Email address: kayikaapsari@gmail.com
}

\section{Introduction}

Company capital as a fulfillment of funds to carry out operational activities can be sourced from internal and external funds. Internal capital sources are sources that originate from business activities in the form of retained earnings, but internal capital is very limited, so additional capital is needed from third parties to support business activities. External funding sources are sources of funds obtained from external parties or third parties in the form of debt and other funds obtained from suppliers, banks and capital markets (Sukardi, 2009).

a Udayana University, Denpasar, Indonesia

${ }^{\mathrm{b}}$ Udayana University, Denpasar, Indonesia 
When the crisis hit Indonesia in 1998, small and medium scale companies were relatively able to survive compared to large companies. The reason is that the majority of small-scale companies are not too dependent on large capital or foreign loans in dollar exchange rates. So, when there is fluctuation in exchange rates, large-scale companies that generally always deal with foreign currencies are the most potentially affected.

One financial strategy that is highly applied in relation to a company's life cycle is in terms of funding decisions or capital structure. The problem of capital structure is an important problem for every company, because of the merits of the company's capital structure will have a direct impact on the financial position of the company.

Mistakes in determining capital structure will have a broad impact if the company is too large in using debt so that the fixed burden that must be borne by the company is getting bigger too. It also means that it will increase financial risk, which is the risk when a company cannot pay interest expenses or installments on debt.

Damodaran (2001), argues that the need for funding sources originating from internal and external at each stage of the company's life cycle is largely determined by the company's ability to obtain cash flow and the level of risk preference. In general, at the founding stage, many sources of company funds come from company founders (internal funding sources) and bank debt. At the expansion stage, the increase in funding needs is met from investment. In the high growth stage, the company becomes a public company (external funding source). In the maturity stage, the need for external funds begins to decline due to relatively adequate internal funding sources. In the last stage, the declining stage, the need for external and internal funds dropped dramatically (Tripathy, 2018; Putri \& Sujana, 2018)

The company's life cycle is a study in strategic management science that discusses the development or characteristics of a company's life. Each company will experience five stages of the life cycle, namely the stages of establishment, expansion, high growth, maturity, and decline. At each stage of the company's life cycle, the need for capital size will be different and to meet those needs the company will use a different funding strategy.

At each company life cycle, there are differences in the selection of alternative funding made by the company. In capital structure theory, one of the theories that describe the order of funding needs of the company is the pecking order theory (Dewi \& Dewi, 2017; Ogunsiji \& Ladanu, 2017).

In accordance with the Pecking Order Theory, there is no target debt to equity ratio, because there are two types of equity capital, internal and external. The company prefers the use of funds from internal capital ie funds originating from cash flow, retained earnings and depreciation. The order of use of funding sources with reference to the pecking order theory is internal funds (internal funds), debt (debt) and equity (own capital).

The selection of this funding sequence shows that this funding is based on the level of cost of funds from these sources which are also related to the level of risk of an investment. This theory briefly states that: (a) The company likes internal financing (funding from the company's operating results in the form of retained earnings), (b) If external funding (external financing) is needed, the company will issue the safest securities first, namely starting with the issuance of bonds, then followed by securities that are characterized by options (such as convertible bonds), only finally if still not sufficient, new shares are issued (Palma et al., 2018).

\section{Literature Review and Hypothesis}

According to Napa \& Muljadi (1995), the optimal capital structure can be defined as a capital structure that maximizes the prosperity of the owners or shareholders or maximizes the value of the company or the company's stock price. Another opinion expressed by Weston \& Brigham (1997), the optimal capital structure is a capital structure that optimizes the balance between risk and returns thereby maximizing stock prices.

The company's life cycle is a development or characteristic of a company's life. At each stage of the company's life cycle, the need for capital will be different. To meet these needs the company will use a different funding strategy. Damodaran (2001), in the life cycle analysis of financing theory, describes the funding strategy framework chosen by the company in relation to the life cycle stage of the company.

One financial strategy that is highly applied in relation to a company's life cycle is in terms of funding decisions or capital structure. At each company life cycle, there are differences in the selection of alternative funding made by the company. In capital structure theory, one of the theories that describe the order of funding needs of the company is the pecking order theory.

This study will examine the pecking order theory of companies that are in the life cycle stages of Start-Up, Growth, Mature and Stagnant. Previous research conducted by Bulan \& Yan (2009), found that pecking order theory financing patterns focused on two stages of the life cycle, namely growth and maturity.

Primudyastono (2012), tries to provide a deeper understanding of capital structure theory (pecking order theory) in various company conditions which are categorized according to the concept of life-cycle. The results of this study 
indicate that the highest average proportion of debt use occurs during the growth phase. Meanwhile, the average proportion of debt usage during the introduction phase is not so different from the maturity phase.

Monica (2017), examines the application of pecking order theory to companies in a surplus condition. Companies in surplus conditions were chosen because the majority of research in pecking order theory in Indonesia only focused on one or a few sectors. Pecking order theory was chosen because this theory is a dynamic theory in accordance with an imperfect market compared to other capital structure theories. The findings of the study are that non-financial companies in Indonesia do not follow the pecking order theory, surplus companies do not follow the pecking order theory to repay debts in advance and surplus companies do not pay debts using their own surplus.

\section{Hypothesis}

H1: Company Life Cycle in the Start Upcycle effect funding decisions (Pecking Order Theory).

H2: Company Life Cycle in the Growth cycle effect funding decisions (Pecking Order Theory).

H3: Company Life Cycle in the Mature cycle effect funding decisions (Pecking Order Theory).

H4: The Company's Life Cycle in the Stagnant cycle effect the funding decision (Pecking Order Theory).

\section{Materials and Methods}

This research was conducted at a Property and Real Estate company listed on the Indonesia Stock Exchange (IDX), which presents financial reports on the official website of the Indonesia Stock Exchange www.idx.co.id. The time of the study was 2013-2017. The population in this study are all Property and Real Estate companies listed on the Indonesia Stock Exchange in the period 2013-2017. The sampling technique used in this study is saturated sampling. In this study data collection is done by observing, recording and analyzing the financial statements of property and real estate companies listed on the Indonesia Stock Exchange. Data analysis techniques in this study used multiple linear regression analysis.

\section{Results and Discussions}

\subsection{Multiple Linear Regression Analysis}

This analysis is used to determine the effect of Life Cycle on the Start-Up, Growth, Mature and Stagnant Phase of the funding decision (Pecking Order Theory).

Table 1

Start-up phase

\begin{tabular}{|c|c|}
\hline \multirow[t]{2}{*}{ Model } & \multirow[t]{2}{*}{ Sig. } \\
\hline & \\
\hline \multirow[t]{2}{*}{1} & . \\
\hline & . \\
\hline
\end{tabular}

Primary Data, 2019

Table 2

Growth Phase

\begin{tabular}{|c|c|c|c|c|c|}
\hline \multirow[t]{2}{*}{ Model } & \multicolumn{2}{|c|}{$\begin{array}{l}\text { Unstandardized } \\
\text { Coefficients }\end{array}$} & \multirow{2}{*}{$\begin{array}{l}\text { Standardized } \\
\text { Coefficients } \\
\text { Beta }\end{array}$} & \multirow[t]{2}{*}{$\mathrm{t}$} & \multirow[t]{2}{*}{ Sig. } \\
\hline & $\mathrm{B}$ & Std. Error & & & \\
\hline (Constant) & .009 & .240 & & .036 & .972 \\
\hline Growth Phase & .468 & .262 & .444 & 1.787 & .097 \\
\hline
\end{tabular}

Primary Data, 2019

Apsari, I. A. K., \& Rasmini, N. K. (2019). The pecking order theory testing on company life cycle. International Research Journal of Management, IT and Social Sciences, 6(5), 101-107. https://doi.org/10.21744/irjmis.v6n5.704 
Table 3

Mature Phase

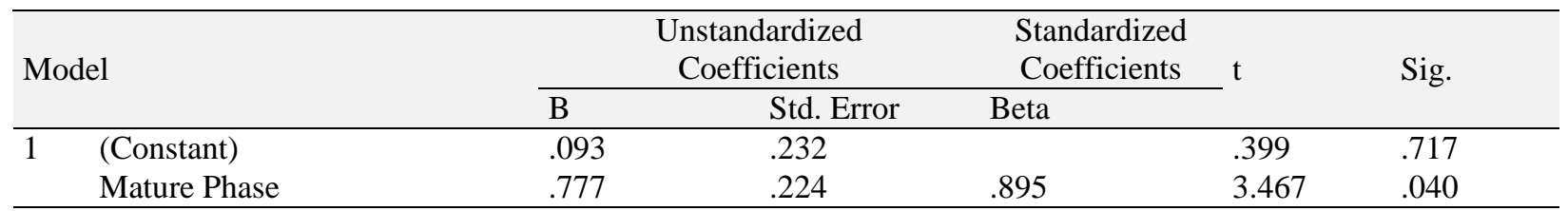

Primary Data, 2019

Table 4

Stagnant Phase

\begin{tabular}{lllcccc}
\hline \multirow{2}{*}{ Model } & \multicolumn{2}{c}{$\begin{array}{c}\text { Unstandardized } \\
\text { Coefficients }\end{array}$} & \multicolumn{2}{c}{$\begin{array}{c}\text { Standardized } \\
\text { Coefficients }\end{array}$} & \multirow{2}{*}{ Sig. } \\
\cline { 2 - 5 } & & $\mathrm{B}$ & Std. Error & Beta & & \\
\hline 1 & (Constant) & -.406 & .201 & & -2.015 & .055 \\
& Stagnant Phase & 3.950 & 1.144 & .576 & 3.453 & .002 \\
\hline
\end{tabular}

Primary Data, 2019

\subsection{Company Life Cycle in the Start-Up phase effect funding decisions (Pecking Order Theory)}

The first hypothesis (H1) proposed in this study is that the Company's Life Cycle in the Start Upcycle influences funding decisions (Pecking Order Theory). The results of the study presented in Table 1 cannot provide output results because the number of sample companies in the start-up phase is less than 5 companies, so the first hypothesis cannot be concluded.

\subsection{Company Life Cycle in the Growth phase effect funding decisions (Pecking Order Theory)}

The second hypothesis (H2) proposed in this study is that the Company's Life Cycle in the Growth cycle influences funding decisions (Pecking Order Theory). Based on the results of the analysis of the influence of the company's life cycle in the growth cycle on the funding decision (Pecking Order Theory) in Table 2 obtained a significance value of 0.097 with a positive regression coefficient of 0.468 . The significance value of $0.097>0.050$ indicates that $\mathrm{H} 2$ is rejected. These results mean that the company's life cycle in the growth cycle has no effect on funding decisions (Pecking Order Theory). Then the second hypothesis is rejected. At the growth stage, the company will experience liquidity problems because it relies too much on short-term funding sources due to limited long-term funds. In the high growth stage, the company becomes a public company (external funding source). Based on Arifin (2009), research, the results show that companies in the growth phase tend to use debt as a choice of corporate capital. Companies in the growth stage require many additional sources of funding, not only in internal funding but also external funding.

\subsection{Company Life Cycle in the Mature phase effect funding decisions (Pecking Order Theory)}

The third hypothesis (H3) proposed in this study is that the Company's Life Cycle in the Mature cycle influences funding decisions (Pecking Order Theory). Based on the results of the analysis of the influence of the company's life cycle in the mature cycle of the funding decision (Pecking Order Theory) in Table 3 obtained a significance value of 0.040 with a positive regression coefficient of 0.777 . The significance value of $0.040<0.050$ indicates that $\mathrm{H} 3$ is accepted. This result means that the company's life cycle in the mature cycle influences the funding decision (Pecking Order Theory). Then the third hypothesis is accepted. Every company will experience a life cycle that is the stages of establishment, growth, maturity, and decline. At each stage of this life cycle, the need for capital will be different. To meet these needs the company will use a different funding strategy. At the mature stage, the need for external funds begins to decline due to relatively sufficient internal funding sources.

Companies at the mature stage where they have high profits usually use the profits to reduce debt. As a result, at this stage, the portion of corporate debt is the lowest (Wokukwu, 2000). Companies in the mature stage should be able 
to reduce the portion of their debt by making use of a large starting profit balance. In this study, the company's life cycle in the mature cycle influences the company to implement its funding decisions (Pecking Order Theory).

\subsection{Determination Coefficient $\left(R^{2}\right)$}

The test results give results in which the adjusted R2 size of the Life Cycle model in the Growth Phase (X2) is 0.135. This means that variations in funding decisions (Pecking Order Theory) can be significantly influenced by the Life Cycle variable in the Growth Phase of 13.5 percent while the remaining 86.5 percent is explained by other factors not explained in the research model.

The test results give results in which the life R2 cycle adjusted R2 model in the Mature Phase (X3) is 0.734. This means that variations in funding decisions (Pecking Order Theory) can be significantly influenced by the Life Cycle variable in the Mature Phase of 73.4 percent while the remaining 26.6 percent is explained by other factors not explained in the research model.

The test results give results in which the magnitude of the adjusted R2 Life Cycle model in the Stagnant Phase (X4) is 0.304 . This means that variations in funding decisions (Pecking Order Theory) can be significantly influenced by the Life Cycle variable in the Stagnant Phase of 30.4 percent while the remaining 69.6 percent is explained by other factors not explained in the research model.

\subsection{Simultaneous Test Results (Test F)}

The feasibility test of the regression model aims to find out whether all identified independent variables (Life Cycle in the Start-Up, Growth, Mature and Stagnant Phase) are appropriate to predict funding decisions (Pecking Order Theory). This test is often also called the F test. The results of the F test can be seen in the following Table 5:

Table 5

F Testing Result

\begin{tabular}{lll}
\hline Information & F Value & F Significant \\
\hline Life Cycle on Start-Up phase $\left(\mathrm{X}_{1}\right)$ & - & - \\
Life Cycle on Growth phase $\left(\mathrm{X}_{2}\right)$ & 3,193 & $0,097^{\mathrm{a}}$ \\
Life Cycle on Mature phase $\left(\mathrm{X}_{3}\right)$ & 12,019 & $0,040^{\mathrm{a}}$ \\
Life Cycle on Stagnant phase $\left(\mathrm{X}_{4}\right)$ & 11,922 & $0,002^{\mathrm{a}}$ \\
\hline
\end{tabular}

Primary Data, 2019

The results of the F test (F test) on the Life Cycle of the Start-Up and Growth Phase show a significance value of Pvalue more than $\alpha=0.05$. This result gives the meaning that all independent variables namely Life Cycle in the Start$\mathrm{Up}$ (X1) and Growth (X2) Phase are not quite right to predict or explain the phenomenon of a funding decision (Pecking Order Theory). In other words, Life Cycle in the Start-Up (X1) and Growth (X2) phases simultaneously does not significantly influence the funding decision (Pecking Order Theory).

The results of the F test (F test) on the Life Cycle of Mature (X3) and Stagnant (X4) stages show a significance value of P-value of 0.040 and 0.002 , respectively, less than $\alpha=0.05$, this means the regression model used in this study is feasible. These results give the meaning that all independent variables namely Life Cycle Mature (X3) and Stagnant (X4) phase correctly predict or explain the phenomenon of a funding decision (Pecking Order Theory). In other words, the Mature and Stagnant Life Cycle simultaneously has a significant effect on funding decisions (Pecking Order Theory).

\section{Conclusion}

1) From the research results obtained, the funding decisions examined in this study are only limited to internal funding decisions, therefore for further research can examine other sources of funding decisions so as to describe the company's overall funding decisions.

Apsari, I. A. K., \& Rasmini, N. K. (2019). The pecking order theory testing on company life cycle. International Research Journal of Management, IT and Social Sciences, 6(5), 101-107. https://doi.org/10.21744/irjmis.v6n5.704 
2) From the research results obtained, the suggestion aimed at further researchers is in classifying the company's life cycle can use a more varied number of company samples compared to this study, given the limited number of companies engaged in the field of Property and Real Estate.

3) Not all variables that allegedly affect the company's funding decisions apply the Pecking Order Theory understudy given the limited information obtained because researchers only use information from the company's annual financial report, therefore it is necessary to examine other variables using sources broader data.

\section{Conflict of interest statement}

The authors declared that they have no competing interest.

Statement of authorship

The authors have a responsibility for the conception and design of the study. The authors have approved the final article.

\section{Acknowledgments}

The authors would like to thank the editor of IRJMIS for their valuable time, support, and advice in completing the present research. 


\section{References}

Arifin, Z. (2009). Evaluasi pembelajaran (Vol. 152). Bandung: PT Remaja Rosdakarya.

Awat, N. I, dan Muljadi. 1995. Keputusan Keputusan Keuangan Perusahaan: Teori dan Hasil Pengujian Empiris, Yogayakarta: Liberty.

Brigham, E. F. (1997). dan Weston J.

Bulan, L. T., \& Subramanian, N. (2009). The firm life cycle theory of dividends. Dividends and dividend policy, 201213.

Damodaran, A. (1997). Corporate Finance. Theory and Practice, John Wiley\&Sons. Inc. Newyork.

Dewi, I. G. A. A. O., \& Dewi, I. G. A. A. P. (2017). Corporate social responsibility, green banking, and going concern on banking company in Indonesia stock exchange. International Journal of Social Sciences and Humanities, 1(3), 118-134. https://doi.org/10.29332/ijssh.v1n3.65

Monica, J., \& Pramesti, M. (2017). Pengujian Pecking Order Theory terhadap Perusahaan Surplus Non Keuangan di Bursa Efek Indonesia. Journal of Technology Management, 16(2), 185-196.

Nehru, R. (2016). Corporate social responsibility \& education for sustainable development. International Research Journal of Engineering, IT \& Scientific Research, 2(3), 72-81.

Ogunsiji, A., \& Ladanu, W. (2017). A theoretical study of performance measures in the strategic and corporate entrepreneurships of firms. International Journal of Physical Sciences and Engineering, 1(1), 72-80. https://doi.org/10.21744/ijpse.v1i1.15

Palma, C. A. M., Pérez, A. V., Gamez, M. R., \& Torres, L. T. M. (2018). A house a small company. International Journal of Physical Sciences and Engineering, 2(1), 26-34. https://doi.org/10.29332/ijpse.v2n1.85

Primudyastono, B. Y. (2012). Pengujian teori pecking order pada life-cycle perusahaan di Indonesia (Doctoral dissertation, Universitas Gadjah Mada).

Putri, Y. K. W., \& Sujana, I. K. (2018). The influence of bid-ask spread and leverage on earnings management with good corporate governance as moderating variable. International Research Journal of Management, IT and Social Sciences, 5(3), 8-21.

Sukardi, A. (2009). Participatory governance dalam pengelolaan keuangan daerah. LaksBang.

Tripathy, M. (2018). Building quality teamwork to achieve excellence in business organizations. International Research Journal of Management, IT and Social Sciences, 5(3), 1-7.

Wokukwu, K. C. (2000). Life cycle and capital structure: some empirical evidence. Nova Southeastern University.

Apsari, I. A. K., \& Rasmini, N. K. (2019). The pecking order theory testing on company life cycle. International Research Journal of Management, IT and Social Sciences, 6(5), 101-107. https://doi.org/10.21744/irjmis.v6n5.704 